Vol. 3, No. 1, Januari 2019, 1-9

Available Online at https://ejournal.warmadewa.ac.id/index.php/kulturistik

DOI: dx.doi.org/10.22225/kulturistik.3.1.934

\title{
PSYCHOLOGICAL ANALYSIS OF PROTAGONIST IN ROWLING'S HARRY POTTER AND THE SORCERER STONE
}

\author{
Gusti Ayu Made Rai Suarniti \\ Warmadewa University \\ raisuarniti78@gmail.com
}

\begin{abstract}
The title of this paper is "Psychological Analysis of Protagonist in Rowling's Harry Potter and The Sorcerer Stone. The aims this study were to find out the psychological problems of protagonist in it his case the problems of emotional feelings that showed in the story and also the influence of protagonist emotional feelings to his surroundings or his self. The data were collected by reading the novel thoroughly then using the note-taking technique before being identified into Psychology aspect. The collected data were descriptively analyzed by using qualitative-descriptive method to classify the types of protagonist emotional feelings and influence of protagonist emotional feelings to his surroundings or his self-found in the novel. Based on the result of the analysis, it is found there are two kinds of emotional feelings, those are: negative emotional feeling and positive emotional feeling. And the analysis he focused on the psychological analysis of protagonist in dealing with his emotion that showed in the story. According to the data, protagonist emotion can influence his surrounding and his self. It make emotional feeling become an influencer of a situation.
\end{abstract}

Keywords: psychology, protagonist, emotional feeling

\section{INTORODUCTION}

Many ways to express ideas and mind concepts, especially in a literary work. There is a literary work that give us the world of fantasy and take us away from real world. That makes literary works have different meanings according to our interpretation. Literature is a social institution, using its medium language, a social creation (Wellek \& Warren, 1956). Literature as an expression of feeling including experience, motivation, idea, confidence in the concrete description by using language. Literature can be classified according to whether it is fiction or non-fiction and whether it is poetry or prose, it can be further distinguished according to major forms such as the novel, short story or novellas, and works are often categorized according to historical periods or their adherence to certain aesthetic features or expectations (genre).

Novel as a literary work has a long narrative, novels generally thought of as containing about forty-five thousand words or more (Kenney, 1966) normally in prose which describes fictional characters and events, usually in form of a sequential story. Character are the aggregate of features and traits that form the individual nature of some person or thing. These people are fictional and their personal qualities and actions are limited by their function in the drama. In terms of role, characters can be divided into protagonist and antagonist characters. The 
Vol. 3, No. 1, Januari 2019, 2

Available Online at https://ejournal.warmadewa.ac.id/index.php/kulturistik

DOI: dx.doi.org/10.22225/kulturistik.3.1.934

protagonist is the center of the story, should be making the difficult choices and key decisions, and should be experiencing the consequences of those decisions. The Protagonist can affect the main characters decisions. The protagonist should be propelling the story forward. Otherwise, the antagonist is a character, group of characters, institution, or concept that stands in or represents opposition against which the protagonist must contend. In other words, an antagonist is a person or a group of people who opposes a protagonist.

Characterization as one of the elements structure of prose fiction. Characterization is method of author to show a fictional person personalities or traits. Through the character the author can reveal persons personalities, so the readers can understand what the author means, by displaying the characterization of the character, the reader will get their emotional feeling. Emotions play a central role in the significant events of our lives. Although they have many characteristics, some behavioral and others physiological, emotions are above all psychological. We feel proud when our loved ones do something worthy. When demeaned, we become angry or ashamed. We experience joy at the birth of our children, anxiety when threatened, and grief at the death of a loved one (Lazarus, 1991).

Emotional feeling can be expressed in various way, especially emotional feelings of the protagonist in novel Harry Potter and The Sorcerer's Stone by J.K. Rowling. This novel is one of the best novel in the world as book sales as much as $\$ 4000$. This book tells the story of young witch who has an interesting story. According to the background of study and the book achievements, the writer interesting to analyze The Protagonist Emotional Feelings of Rowling's Harry Potter and The Sorcerer's Stone especially deal with the emotional feeling of the protagonist in here, the emotional feeling of Harry in facing his life, and his story in his school. Story indicated by his characterization in his conversation and the psychology of protagonist in this novel.

\section{METHOD}

Method of research is needed in conducting a research. Method of research is the explanation about what method that is applied by the researchers in doing their research. Method is a particular way of doing something. In order to get the expected and required result, method should be used in comprehensive way. There are three steps of research method, namely: data source, data collection, and data analysis.

The data source in this scientific writing will be taken from the novel of J.K. Rowling's Harry Potter and The Sorcerer's Stone. The data collection is collected by using library research. The data will be collected through the process of reading the novel very carefully. Then, the text that have relationship with the topic are observed to identify the protagonist emotional feelings. The relevant data will be underlined and written down in the data list. Then, the data that have been written in the data list will be classified based on the protagonist emotional feelings.

The data analysis will be done by using qualitative-descriptive method. The data are analyzed based on the two theoretical basis. First, theory of character proposed by Di Yanni (2001) about understanding of character, Griffith (2006) about development of the traits of character whose supported by Reaske (1984) about protagonist or antagonist, Abrams about dramatic or narrative way in characterizations, Lajos Egri (1923) about Three dimensions of characterization , For- 
Vol. 3, No. 1, Januari 2019, 3

Available Online at https://ejournal.warmadewa.ac.id/index.php/kulturistik

DOI: dx.doi.org/10.22225/kulturistik.3.1.934

ster (1974) about simple or complex character. While, theory of psychology proposed by Lazarus (1991) about emotion whose supported by Kasschau (2003) about behavior or mental process, Santrock (2003) about systematic methods of psychology, Bernhards (1953) about psychology as activities of individuals, and finally, supported by Feldman about emotion as motives. The problems which discussed in this paper are solved based on the theories, then the data will be presented using informal method. The informal method was applied by using some sentences or languages which is easy to be understood.

\section{DISCUSSION}

\section{Psychological Problems of Protagonist Emotional Feeling}

The analysis Protagonist Emotional Feelings of Rowling's Harry Potter and The Sorcerer Stone can be divided into two part such as: positive emotion and negative emotion. The analysis can be explained from the quotes that find in Rowling's Harry Potter and The Sorcerer Stone. There are some types of emotional feelings of protagonist. Those are negative emotional feeling and positive emotional feeling. The analysis can be explained as follows:

\section{Negative Emotional Feelings}

Negative emotional feeling of protagonist happened when Harry Potter is nearly eleven years old in that time, his parents had murdered by Voldemort the powerful dark wizard. Little harry took care by his uncle, Dursley, and he lived in Dursley's family. Harry felt uncomfortable in the family especially when his aunt wakes Harry in the early morning. His aunt demand Harry to help her on this morning. The analysis can be explained by the following quotation:

"His aunt was back outside the door."

"are you up yet?" she demanded."

"nearly," said Harry."

"Well, get a move on, I want you look after the bacon. And don't you dare let in burn, I want everything perfect on Duddy's birthday."

"Harry groaned"

"What did you say?" his aunt snapped through the door."

"Nothing, nothing." (Rowling, 1997: 14)

From the quotation above, Harry shows negative emotion. That emotion is anger. The protagonist emotional feelings influenced his aunt because Harry show his negative emotion to his aunt when he got woke by his aunt, Harry angry with his aunt because Harry felt disturbed of his aunt. Harry's emotion triggered his aunt become angry too. His aunt felt angry when Harry groaned to his aunt it make Harry look like a lazy boy.

Harry show his emotional feeling when the Dursley's pick Harry into the sack in the ocean. The Dursley's move to the ocean because they got the mail terror on the house where they live before. When the Durlseys has sleep, suddenly a big man kicked the door in order to find Harry, and a big man give him present because Harry has a birth day at that time. Harry who don't know Hagrid, Harry feel confuse and anxiety of him. The analysis can be explained as the following quotation:

"Anyway - Harry," said the giant, turning his back on the Dursley's, "a very happy birthday to yeh. Got summat fer yer here - I mighta sat on it at some 
Vol. 3, No. 1, Januari 2019, 4

Available Online at https://ejournal.warmadewa.ac.id/index.php/kulturistik

DOI: dx.doi.org/10.22225/kulturistik.3.1.934

point, but it'll taste all right."

"From an inside pocket of his black overcoat he pulled a slightly squashed box. Harry opened it with trembling fingers. Inside was a large, sticky chocolate cake with Happy Birthday harry written on it in green icing." (Rowling, 1997: 36)

From the quotation above, Harry shows negative emotion. That emotion is anxiety. Harry anxiety to the big man who suddenly come to him and give him present for him birth day and Harry don't know who the big man. Harry influenced his situation Harry feel anxiety with the giant who suddenly come to him and give him present for him birth day.

After Harry bought some his school requirement from Diagon Alley, Harry is ready to go to Hogwarts. Harry go to Hogwarts through the special station. After a long journey, Harry has arrived in Hogwart. There Harry greeted by Professor McGonagal. Before Harry doing his study, McGonagal do a sorting ceremony for all student. The sorting ceremony is a ceremony of group where the student lived. Emotional feeling of protagonist begin when the sorting ceremony started. When Harry's turn, he wish not to be a Slytherin, he want to join with his friend in Gryffindor. Harry wishes to the sorting hat he want to be a Gryffindor. Harry felt anxiety when he waiting for a decision of the sorting hat. Finally, the sorting hat make a decision to put Harry in the Gryffindor house. The analysis can be explained by the following quotation:

"Harry gripped the edges of the stool and thought, not Slytherin, not Slytherin." (Rowling, 1997: 97)

From the Quotation above, Harry shows negative emotion. Harry feel anxiety because Harry no need to join in Slytherin. Harry influence the sorting hat to not put him into the Slytherin. Harry's emotion make the magic hat think twice to put him into the Slytherin. When Harry felt anxiety of his decision, the sorting hat make the Harry wishes come true and put Harry into the Gryffindor house.

Harry live his life to be a wizard student at Hogwart. He study anything about magic. Harry is a good student, he can do magic more best than his other friend, he so talented. When he study about flying, Emotion shows when Harry on his flying training. At that time Harry see Malfoy take something on the grass, and that thing is a Neville's magic ball, Harry try to take it back, but Malfoy didn't want to give that thing to harry. Malfoy persuade Harry to fly if he want to take that thing. The analysis can be explained by the following quotation:

"Harry ignored her. Blood was pounding in his ears. He mounted the broom and kicked hard against the ground and up, up he soared..." (Rowling, 1997: 118)

From the quotation above, Harry shows negative emotion. He feel angry with Malfoy who take Neville's things. Harry try to take back that thing without he hears what his friend said. Harry influence his self. Anger of Harry make him braver. He brave to drive his broom stick at the first time. Harry who don't controlled his broom stick before, suddenly he can control it. Harry success take the Neville's things back from Malfoy.

After the accident in flying training, Professor McGonagal saw Harry flied for his first time. Harry can fly like a professional it made Professor McGonagal 
Vol. 3, No. 1, Januari 2019, 5

Available Online at https://ejournal.warmadewa.ac.id/index.php/kulturistik

DOI: dx.doi.org/10.22225/kulturistik.3.1.934

like with him. Harry recruited by Mcgonagal in Quidditch match because his talent. Emotion shows when the Quidditch game begin. Harry get some trouble in his first Quidditch game. In middle of the match, suddenly his broom going wild. He's don't control his broom and it make he going fear and confuse, because he never felt his broom like that before. The analysis can be explained by the following quotation:

"It was Harrry dodged another Bludger, which went spinning dangerously past his head that it happened. His broom gave a sudden, frightening lurch. For a split second, he thought he was going to fall. He gripped the broom tightly with both his hands and knees. He'd never felt anything like that." (Rowling, 1997: 151)

From the quotation above, Harry shows negative emotion. He feel anxiety. Harry got some trouble on his broom. He didn't controlled his broom it make him frighten. Harry influence his self, he feel anxiety when his broom going wild and uncontrolled. It make he going panic and he almost fall from his broom.

One day Harry had caught by Professor McGonagall because Harry break the rule. Emotion shows when Professor McGonagall giving punishment to Harry and his friend. Harry get his punishment because he break the rules of out of bed in the night. Harry receives his detentions, reducing fifty point of his group. The analysis can be explained by the following quotation:

"Fifty?" Harry gasped - they would lose the lead, the lead he'd won in the last Quidditch match.” (Rowling, 1997: 195)

From the quotation above, Harry shows negative emotion. Harry feel sad when his point got taken by Professor McGonagall and the point who got by Harry in the Quidditch match was useless". Harry influenced his surroundings. The punishment make the Gryffindor lost its point.

After Harry got his punishment, emotion shows when the Gryffindor put in last place of house cup because Harry and his friend feel guilt of this accident. The analysis can be explained by the following quotation:

"A hundred and fifty points lost. That put Gryffindor in last place. In one night, they ruined any chance Gryffindor had had for the house cup. Harry felt as though the bottom had dropped out of his stomach, how could they ever make up for this?" (Rowling, 1997: 195)

From the quotation above, Harry shows negative emotion. He feel guilt of what he had been done. He feel guilt when he was broke the rule of out of be in the night and his group had reduced point. Beside that Harry feel angry because the punishment is too big.

Emotion shows when Harry try to find the sorcerer's stone. In the journey to find the stone, Harry trough many place and obstacle in front of him. When Harry arrived in the large chessboard, Harry and his friends struggling to pass the chessboard with play a chess against large magic chest. With a Ron's skill in the chess game, Harry and his friend success to win the game and can pass into the next chambers.

"The white took off his crown and threw it at Harry's feet. They had won. The chessmen parted and bowed, leaving the door ahead clear with one last desperate look back at Ron, Harry and Hermione charged through the door 
Vol. 3, No. 1, Januari 2019, 6

Available Online at https://ejournal.warmadewa.ac.id/index.php/kulturistik DOI: dx.doi.org/10.22225/kulturistik.3.1.934

and up the next passageway." (Rowling, 1997: 228)

From the quotation above, Harry show negative emotion. Harry feel sad because Ron wound on his game. Ron had sacrificed to open the way for Harry. Harry influenced his surroundings. When he feel sad his friend sad to it make the situation going sad.

After Harry won the chess game, Harry continue his journey to find the sorcerer stone. Emotion shows when Harry enter a room which a disgusting smell. The analysis can be analyzed as the following quotation:

"A disgusting smell filled their nostrils, making both of them pull their robes up over their noses. Eyes watering, they saw, flat on the floor in front of them, a troll even larger than the one they had tackled, out cold with a bloody lump on its head."

"I'm glad we didn't have to fight that one," Harry Whispered as they stepped carefully over one of its massive legs." Come on, I can't breathe" (Rowling, 1997: 228)

From the quotation above, Harry shows negative and positive emotion. Harry feel disgust when he enter next room after the chessboard. He pull his robes up over his noses it indicated he doesn't like the smell.

Finally Harry meet Quirrell and Voldemort in the last chamber. Harry see the magic mirror in the center of them. Harry close to the mirror and see a sorcerer's stone inside the mirror and he take the sorcerer's stone quietly. Voldemort want to take the sorcerer's stone from Harry. Voldemort do anything to get the stone from Harry. Although Voldemort persuade Harry, Harry refused him and try to fight him. The analysis can be analyzed as the following quotation:

"Don't fool," snarled the face. "better save your own life and join me... or you'll meet the same end as your parents... they died begging me for mercy..."

“LIAR!” Harry shouted suddenly.” (Rowling, 1997: 237)

From the quotation above, Harry shows negative emotion. Harry feel angry when Voldemort try to persuade Harry. Harry influence his self and Voldemort. Harry angry because he felt cheated by Voldemort.

Harry success to kill Voldemort and save the sorcerer stone. After the fight, he sudden get blink, he didn't remember after he kill Voldemort. After Harry wake from his blink, Dumbledore come to Harry and say what was happened and Dumbledore tell Harry anything what he ask to Dumbledore. After take some time to rest and some medical check, Harry is going better and at the same time Harry see the Slytherin flag everywhere because the Slytherin won the house cup. The analysis can be analyzed as the following quotation:

"Now, as I understand it, the house cup here needs awarding, and the points stand thus: In fourth place, Gryffindor, with three hundred and twelve points; in third, Hufflepuff, with three hundred and fifty two; Ravenclaw has four hundred and twenty six and Slytherin, four hundred and seventy-two."

"A storm of cheering and stamping broke out from the Slytherin table. Harry could see Draco Malfoy banging his goblet on the table, It was a sickening sight." (Rowling, 1997: 246) 
Vol. 3, No. 1, Januari 2019, 7

Available Online at https://ejournal.warmadewa.ac.id/index.php/kulturistik DOI: dx.doi.org/10.22225/kulturistik.3.1.934

From the quotation above, Harry shows negative emotion. Harry feel jealous with Draco Malfoy who his team won the house cup. Harry influenced his surrounding, Harry feel jealous with Malfoy. His emotion make his friend become jealous too.

In summer, Harry and all student of Hogwart doing their summer holiday. The student back to their home for a summer break. Emotion shows when Harry and his friend come back into each house for summer. They are in summer holiday and the school was free. The analysis can be analyzed as the following quotation:

"Harry hung back for a last word with Ron and Hermione.

"See you over the summer, then." (Rowling, 1997: 248)

From the quotation above, Harry shows negative emotion. Harry feel sad when he split up with his friend for a summer Holiday. Harry influenced his surrounding, when harry feel sad, his friend feel the same with Harry because they will break up for the summer it make the situation going sad.

\section{Positive Emotional Feelings}

For preparing his school requirements, Hagrid bring Harry into the Diagon Alley. Diagon Alley is a market of the wizard. A situation of Diagon Alley was very crowded because too many people in there. Emotion shows when Harry has arrived at Diagon Alley. It's the first time Harry visit Diagon Alley. Harry feel excited with the situation of a crowd of Diagon Alley.

"Harry grinned at Harry's amazement."

"Harry wished he had about eight more eyes. He turned his head in every direction as they walked up the street, trying to look at everything at once: the shops, the things outside them, the people their shopping." (Rowling, 1997: 55)

From the quotation above, Harry shows positive emotion. Harry feel happy when he visit the Diagon Alley for the first time. Harry influence his self. He feel happy about his new experience. Harry feel happy than before, it make Harry become more confidence and Harry more close with Hagrid.

In sorting ceremony of Hogwarts. Harry got his house in Gryffindor. He feel relief when he join with Gryffindor. Emotion shows when Harry join to Gryffindor. He was so relief to have been join to Gryffindor.

"Harry heard the hat shout the last word to the whole hall. He took off the hat and walked shakily toward the Griffindor table. He was so relieved to have been chosen and not put in Slytherin." (Rowling, 1997: 97)

From the quotation above, Harry show positive emotion. Harry feel relief because he join to Gryffindor not to Slytherin. He was so relieved to have been chosen and not put in Slytherin." Harry influence his surroundings. He feel relief because he join in Gryffindor, it make all of Gryffindor member feel happy.

Emotion shows when Harry try to find the sorcerer's stone. In the journey to find the stone, Harry trough many place and obstacle in front of him. When Harry arrived in the large chessboard, Harry and his friends struggling to pass the chessboard with play a chess against large magic chest. With a Ron's skill in the chess game, Harry and his friend success to win the game and can pass into the 
Vol. 3, No. 1, Januari 2019, 8

Available Online at https://ejournal.warmadewa.ac.id/index.php/kulturistik

DOI: dx.doi.org/10.22225/kulturistik.3.1.934

next chambers.

"The white took off his crown and threw it at Harry's feet. They had won. The chessmen parted and bowed, leaving the door ahead clear with one last desperate look back at Ron, Harry and Hermione charged through the door and up the next passageway." (Rowling, 1997: 228)

From the quotation above, Harry shows positive and negative emotion. Harry feel happy when he and his friend win the chess game. Beside that Harry feel sad because Ron wound on his his game. After Harry won the chess game, Harry continue his journey to find the sorcerer stone. Emotion shows when Harry enter a room which a disgusting smell. The analysis can be analyzed as the following quotation:

"A disgusting smell filled their nostrils, making both of them pull their robes up over their noses. Eyes watering, they saw, flat on the floor in front of them, a troll even larger than the one they had tackled, out cold with a bloody lump on its head."

"Im glad we didn't have to fight that one," Harry Wispered as they stepped carefully over one of its massive legs." Come on, I can't breathe" (Rowling, 1997: 228)

From the quotation above, Harry shows negative and positive emotion. Harry feel disgust when he enter next room after the chessboard. He pull his robes up over his noses it indicated he doesn't like the smell. Beside that he feel relief after he know he didn't fight again.

Emotion shows when Professor Dumbledore giving Harry and his friend a some added points because Harry and his friend was played important rule and was did a good action to save Hogwart. Each one of them get some point from Dumbledore, it make their group has an added point, so it change the result of the house cup. That thing make Gryffindor lead the house cup point, so that make Gryffindor win the house cup.

"Someone standing outside the Great Hall might well have thought some sort of explosion had taken place, so loud was the noise that erupted from the Gryffindor table. Harry, Ron, and Hermione stood up to yell and cheer as Neville, white with shock, disappeared under a pile of people hugging him. He had never won so much as a point for Gryffindor before. Harry, still cheering, nudged Ron in the ribs and pointed at Malfoy, who couldn't have looked more stunned and horrified if he'd just had the Body-Bind Curse put on him." (Rowling, 1997: 247)

From the quotation above, Harry shows positive emotion. Harry feel happy when his team Gryffindor change position into the winner of the house cup. Harry influenced his surrounding, Harry feel happy when his team won the house cup, it make his surrounding felt happy too, Harry and his friend feel happy together, and they celebrated their victory with a same feeling.

\section{CONCLUSION}

Based on the basic role of the character, it is clear that Harry Potter is the protagonist character of this story. Harry Potter is a young wizard boy that lived with his uncle because his parent was murdered by Voldmort when his was baby. 
Vol. 3, No. 1, Januari 2019, 9

Available Online at https://ejournal.warmadewa.ac.id/index.php/kulturistik DOI: dx.doi.org/10.22225/kulturistik.3.1.934

There are many psychological problems which are faced by Harry especially the problems of emotional feelings and this analysis is purposed to find Harry's emotional feelings based on this story.

According to Harry's problems, the protagonist emotional feeling shows in two major line, The first line is negative emotional feeling and the second line is a positive emotional feeling. Negative emotional feeling is a negative expression of emotion that showed by protagonist, there are negative emotional feeling that showed by protagonist such as sadness, anxiety, and guilt. Positive emotional feeling is a positive expression of emotion that showed by protagonist, there are positive emotional feeling that showed by protagonist such as Happiness or joy, and relief.

Protagonist emotional feeling can influenced his surrounding or the protagonist own self. The protagonist emotional feelings influenced his aunt because Harry show his negative emotional feeling to his aunt when he got woke by his aunt. In the other side when the protagonist shows his positive emotional feeling it can be a different influenced. The protagonist emotional feelings play central on Harry expression. Through the emotional feeling, the protagonist can show what he feel at that time to other people and emotional feeling of protagonist can influence his surrounding and it make a new motivation in emotion.

\section{REFERENCES}

Bernhardt, K. S. (1953). Practical Psychology. New York Toronto London: The Life Underwriters Association of Canada.

Di Yanni, R. (2001). Literature Readin Fiction, Poetry, and Drama. United States of America: The McGraw-Hill Companies, Inc.

Egri, L. (1923). The Art of Dramatic Writing. New York: Simon and Schuster, Inc.

Forster, E. M. 1974. (1974). Aspect of the Novel. Great Britain: Hazell Watson \& Viney Ltd.

Griffith, K. (2006). Writing Essays about Literature. Canada: Thomson Corporation.

Kasschau, R. A. (2003). Understanding Psychology. United States of America: McGraw Hill Inc.

Kenney, W. (1966). How to Analyze Fiction. New York: Monarch Press.

Lazarus, R. S. (1991). Emotion \& Adaptation. Oxford New York Toronto: Oxford University Press.

Reaske, C. R. (1984). How to A nalyze Drama. New York: Cambridge University Press.

Rowling, J. K. (1997). Harry Potter and The Sorcerer's Stone. United States of America: Criag Philpot.

Santrock, J. W. (2003). Psychology 7. United States of America: McGraw-Hill Companies, Inc.

Wellek, R., \& Warren, A. (1956). Theory of Literature. New York: Harcourt. Brace \& World Inc. 